\title{
Effect of Taurine Supplement on Aerobic and Anaerobic Outcomes: Meta-Analysis of Randomized Controlled Trials
}

Yusuf Buzdağlı ( $\nabla$ yusuf.buzdagli@erzurum.edu.tr)

Erzurum Technical University

Cemre Didem Eyipınar

Near East University

Aslıhan Tekin

İbrahim Çeçen University

Erdinç Şıktar

Erzurum Technical University

Karolina Skonieczna Zydecka

Pomeranian Medical University

\section{Research Article}

Keywords: Taurine, Time to Exhaustion, Vertical Jump, Countermovement Jump, Meta-Analysis

Posted Date: February 14th, 2022

DOI: https://doi.org/10.21203/rs.3.rs-1305885/v1

License: (c) (i) This work is licensed under a Creative Commons Attribution 4.0 International License. Read Full License 


\section{Abstract}

Background: Taurine is a well-known free amino acid that has gained prominence in recent years despite its little or no role in protein formation. Few studies on the ergogenic effect of taurine exist with inconsistent results. The question on whether performance markers show the benefit from the taurine remains open. This study aimed to reach a consensus about whether taurine supplementation is effective on aerobic (time to exhaustion, VO2max, and rating of perceived exertion) and anaerobic (jumping, blood lactate level) performance outputs.

Methods: Google Scholar, Pubmed databases, clinical trial websites, and grey literature were reviewed until November 2021. Mean differences (MDs) were pooled using random or fixed-effects models according to the heterogeneity degree of related outcomes. Although 17 studies were detected for the meta-analysis between 2001-2021, 15 studies were grouped. Only randomized controlled trials (single or double-blind) were considered.

Results: Taurine supplementation had a significant effect on vertical (MD =3.60; $95 \% \mathrm{Cl} 2.32$ to 4.89, $\mathrm{p}<0.00001)$ and countermovement (MD $=8.50 ; 95 \% \mathrm{Cl} 4.78$ to $12.22, \mathrm{p}<0.00001)$ jump performance when compared to a placebo group. Taurine supplementation had no significant effect on VO2max level and rate of perceived exertion (respectively, MD = $-0.54 \mathrm{ml} / \mathrm{kg} / \mathrm{min} ; 95 \% \mathrm{Cl}-6.84$ to $5.75, \mathrm{p}=0.87 ; \mathrm{MD}=-0.24 ; 95 \% \mathrm{Cl}-0.74$ to $0.27, \mathrm{p}=0.35$ ) when compared to a placebo group.

Conclusion: Taurine improves potentially jumping performance and time to exhaustion.

\section{Background}

Taurine is a well-known free amino acid that has expanded in popularity in recent years, plays little or no part in protein biosynthesis. It does, however, provide a variety of physiological functions, including interacting with ion channels, membrane stability, and cellular osmoregulation [1, 2]. Taurine has an intracellular concentration range of around 5 to 20 $\mu \mathrm{mol} / \mathrm{g}$ in many tissues, notably excitable tissues including skeletal muscle, heart, and brain [3]. Meat, shellfish, sea vegetables, and dairy products are the main sources of dietary taurine. The availability of its precursor cysteine affects taurine biosynthesis $[3,4]$.

By oxidizing the precursor cysteine, exercise is a critical component that can affect taurine production. For instance, highintensity-induced redox alteration of cysteine might result in a variety of post-translational modifications that impact taurine production, resulting in either muscular adaptation or tiredness [5]. External taurine sources may be required in this circumstance. Taurine may help to reduce oxidative damage and restore muscle function in people with muscular dystrophy [3-5]. Additionally, taurine-regulated calcium homeostasis can lead to an increase in calcium-binding proteins during muscular contraction, resulting in increased muscle strength and endurance [6-8].

Taurine is commonly used orally in the form of capsules or taurine-rich drinks $[9,10]$. Taurine plasma concentrations rise about 10 minutes after consumption and generally peak ( 0.03 to $0.06 \mathrm{mmoL}) 1$ hour later. Taurine's impact on performance is influenced by various aspects, including taurine ingestion timing, administration type, and exercise technique. Taurine levels return to baseline within 6.5 hours after this absorption phase [9]. In published human trials, taurine dosages ranged from $500 \mathrm{mg} / \mathrm{d}$ to $10 \mathrm{~g} / \mathrm{d}$ [11]. The amount of taurine present in muscle is influenced by training status (higher in trained than untrained muscle and fiber type higher in type I than type II) [12,13]. Taurine has been reported to improve exercise performance $[14,15]$ and reduce recovery time from damaging and stressful exercise in some but not all studies $[16,17]$. According to ISSN's $(2018)$ report, the categories of nutritional supplements vary according to the quality and quantity of scientific studies on supplementation [18]. Taurine is in the "Limited or Mixed Evidence Supporting Efficacy" category according to this ISSN report. It is thought that more scientific studies are needed to prove its efficacy and safety. 
Taurine has been reported to improve exercise performance $[14,15]$ and reduce recovery time from damaging and stressful exercise in some but not all studies $[16,17]$. The ergogenic effects of taurine supplementation are still controversial, according to previous studies. M Waldron et al. [19], found that single daily dosages of 1 to $6 \mathrm{~g}$ for up to two weeks can considerably increase endurance exercise performance. Two research found that taurine might have its role in recovery from muscular injuries and improving resistance exercise performance [20, 21]. Oral intake of $50 \mathrm{mg} / \mathrm{kg} 14$ days before and 7 days after injury boosted strength along with reducing discomfort and muscle damage indicators [21]. Lastly, taurine has been demonstrated to act as an antioxidant, enhancing the cellular environment ability to endure exercise stress $[22,23]$. While more research on taurine is being published, the results of these studies are still equivocal in terms of taurine's ability to improve physical performance $[16,24]$.

A previous review study with taurine supplementation addressed the dose-response relationship in aerobic and strength exercises [24]. No previous meta-analysis has examined the effects of taurine on aerobic and anaerobic exercise outcomes. Therefore, the purpose of this meta-analysis was twofold: to evaluate the effects of taurine intake on i. aerobic and ii. anaerobic outputs. The results are thought to benefit athletes and practitioners in a variety of sports where aerobic and anaerobic capacity and/or power performance are important determinants.

\section{Methods}

\section{Search Strategy and Quality Assessment of Studies}

A systematic literature search was conducted utilizing the PubMed and Google Scholar databases, ClinicalTrials.gov website, and grey literature inputs to find studies published from 2001 to November 2021 that looked at the effects of taurine supplementation on aerobic and anaerobic outputs. "taurine" AND "aerobic performance", "taurine" AND "anaerobic performance" were used as keywords. To confirm that all relevant studies were included in the analysis, a thorough search was conducted via the reference lists of identified related documents. Following the eradication of duplicate articles, each study was evaluated in accordance with predetermined inclusion and exclusion criteria, as stated in Figure 1. to determine which articles were eligible. The Cochrane risk of bias tool for randomized controlled trials has been used to assess the quality of each article. Random sequence generation, allocation concealment, blinding, as well as the detection of incomplete outcome data, selective outcome reporting, and other possible reasons for bias are all included in the Cochrane Risk of Bias tool scale [25].

\section{Study Selection Criteria}

The study inclusion criteria were: (i) healthy individuals and athletes (ii) reporting aerobic or anaerobic performance markers regardless of the nature of the applied exercises (iii) examining the effect of taurine supplementation (iv) all placebo-controlled single and double-blind experimental studies (v) studies in English or Turkish. Studies in which an (i) co-ingestion with other supplements (ii) individuals with chronic diseases took part (iii) different outcomes from aerobic or anaerobic performance markers and (iv) non-randomized controlled trials were excluded from the meta-analysis.

\section{Data Extraction and Outcome Measures}

Extracted data included: (i) information of studies (author's surname, year, study design) (ii) characteristics of the sample (gender, health, and training status, age and weight) (iii) duration of supplementation (iv) dosage and form of taurine supplementation (v) exercise protocols (vi) outcomes of the study (vii) side effects of taurine supplementation. The Preferred Reporting Items for Systematic Reviews and Meta-Analyses (PRISMA) methodology was used to retrieve data. Web-PlotDigitizer (https://automeris.io/WebPlotDigitizer/) was used to read data that was only provided graphically. The intercoder reliability for WebPlotDigitizer is strong, given the fact that it relies on hand plotting (Drevon, Fursa \& Malcolm, 2017). Previous systematic reviews and meta-analyses, including those on various nutritional supplements, have employed WebPlot-Digitizer [19, 26, 27]. 
In this meta-analysis, aerobic outputs were measured with the following indices: time to exhaustion ( $\min$ ), V02max $(\mathrm{ml} / \mathrm{kg} / \mathrm{min})$, and perceived effort; in the case of anaerobic outputs we retrieved data on blood lactate level ( $\mathrm{mmol} / \mathrm{I})$ and vertical and countermovement jumping (cm). All data extracted as mean and standard deviation (SD) of taurine and placebo post measurements. Then, it is entered into the excel sheet and transferred into the meta-analysis program.

\section{Statistical Analyses}

Time to exhaustion ( $\mathrm{min}$ ), V02max ( $\mathrm{ml} / \mathrm{kg} / \mathrm{min}$ ), and degree of perceived exertion (score) were used to choose results for aerobic performance, while vertical and countermovement jumping $(\mathrm{cm})$ and blood lactate level $(\mathrm{mmol} / \mathrm{l})$ were used to select results for anaerobic performance. In the meta-analysis, raw data in the form of a mean, SD, and sample size for taurine and placebo groups were extracted. Unreported values obtain from WebPlotDigitizer (Version 3.12). The metaanalysis of aerobic and anaerobic performance outputs was conducted using Review Manager 5.4 (Cochrane's Software).

The mean differences were used for continuous outcomes to estimate the effects of taurine. The data was analyzed using fixed-effects or random-effects models dependent on the degree of heterogeneity as measured by the $\mathrm{I}^{2}$ statistic. The mean differences between taurine and placebo groups were expressed using Hedges' $\mathrm{g}$ and 95 percent confidence intervals (Cls) across trials. MDs of $\leq 0.2,0.2-0.49,0.5-0.79$, and $\geq 0.8$ were considered to represent small, medium, large, and very large effects, respectively [28]. To evaluate the tests for the forest plots, subgroup analysis, and quality assessment, Review Manager version 5.4 was utilized. For all analyses, the statistical significance level was set at $p<0.05$.

\section{Register}

PROSPERO recording of our work titled "Does Taurine Supplementation Affect Aerobic and Anaerobic Outputs? A MetaAnalysıs of Randomized Controlled Trials" with ID 291146 has been made. However, the protocol of this review was not registered in PROSPERO since this platform does not accept systematic reviews assessing sports performance as an outcome.

\section{Results}

\section{Study Selection}

For this meta-analysis, a total of 17.880 studies were identified. Duplications were eliminated and the remaining 169 relevant studies were assessed based on their title and abstract. In total, 153 of studies were excluded due to the following reasons: co-ingestion of other supplements $(n=14)$, relevant measurements not taken $(n=124)$, animal studies $(n=7)$, participants with chronic health status $(n=3)$, not open access study $(n=1)$, meta-analysis $(n=2)$ and systematic review $(n=2)$. Ultimately, the current analysis involves 17 studies. Figure 1. depicts the selection procedure.

Although 17 studies were detected for the meta-analysis between 2001-2021, 15 studies were grouped. Only randomized controlled trials (single or double-blind) were considered.

\section{Characteristics of the Included Studies}

There were 202 participants (128 athletes and 74 healthy individuals) from 17 studies included in the present metaanalysis. The studies' sample sizes ranged from 7 [29] to 21 [30] subjects. The participants' ages ranged from 17 [31] to 34.6 [10] years old on average. One of the research [32] included females, whereas the others employed males. The duration of supplementation varied from acute to eight weeks. The daily doses of taurine given vary between 1 and 10 $\mathrm{g} / \mathrm{d}$. gram of taurine was the most common dosage. Swimming, running, jumping, cycling performance, and treadmill or cycle ergometer testing were all part of the exercise regimen. In 10 of the 17 studies [10, 14-16, 29, 30, 32-35], found had aerobic outputs, 6 studies [31, 36-40] had anaerobic outputs, and 1 study [41] both aerobic and anaerobic outputs were provided. 
Characteristics of included studies concerning aerobic, and anaerobic performance outputs are presented in Tables 1. and 2 .

Table 1 Characteristics of Included Studies Related to Aerobic Outputs $(n=11)$

Table 2 Characteristics of Included Studies Related to Anaerobic Outputs ( $n=7$ ) 


\begin{tabular}{|c|c|c|c|c|c|c|c|c|}
\hline $\begin{array}{l}\text { Author, } \\
\text { Year }\end{array}$ & $\begin{array}{l}\text { Study } \\
\text { design }\end{array}$ & $\begin{array}{l}\text { Sample } \\
\text { group and } \\
\text { total size }\end{array}$ & $\begin{array}{l}\text { Mean } \\
\text { age (yr) } \\
\text { and } \\
\text { body } \\
\text { weight } \\
(\mathrm{kg})\end{array}$ & Duration & $\begin{array}{l}\text { Dosage } \\
\text { and form } \\
\text { of Taurine }\end{array}$ & Exercise Protocols & Results & $\begin{array}{l}\text { Side } \\
\text { Effect }\end{array}$ \\
\hline
\end{tabular}

\begin{tabular}{|c|c|c|c|c|c|c|c|}
\hline $\begin{array}{l}\text { TG } \\
\text { Balshaw } \\
\text { et al. [16] }\end{array}$ & $\mathrm{RDB}$ & $\begin{array}{l}8 \text { male } \\
\text { middle- } \\
\text { distance } \\
\text { runners }\end{array}$ & $\begin{array}{l}19.9 \mathrm{yr} / \\
69.4 \mathrm{~kg}\end{array}$ & Acute & $\begin{array}{l}1 \mathrm{~g} / \mathrm{d} \\
\text { Capsule }\end{array}$ & $\begin{array}{l}\text { 3-km running } \\
\text { performance on } \\
\text { the treadmill }\end{array}$ & $\mathrm{VO}_{2 \max }$ \\
\hline
\end{tabular}

\begin{tabular}{|c|c|c|c|c|c|c|c|}
\hline $\begin{array}{l}\text { FG De } \\
\text { Carvalho } \\
\text { et al. [33] }\end{array}$ & $\mathrm{RDB}$ & $\begin{array}{l}10 \text { male } \\
\text { triathletes }\end{array}$ & $\begin{array}{l}30.9 \mathrm{yr} / \\
77.45 \\
\mathrm{~kg}\end{array}$ & 8 weeks & $\begin{array}{l}3 \mathrm{~g} / \mathrm{d} \\
\text { Capsule }\end{array}$ & $\begin{array}{l}\text { A maximal } \\
\text { incremental } \\
\text { running test }\end{array}$ & RPE * \\
\hline
\end{tabular}

\begin{tabular}{|c|c|c|c|c|c|}
\hline $\begin{array}{l}\text { BS Galan } \\
\text { et al. [34] }\end{array}$ & $\mathrm{RDB}$ & $\begin{array}{l}9 \text { male long- } \\
\text { distance } \\
\text { triathletes }\end{array}$ & $\begin{array}{l}30 \mathrm{yr} / \\
78.45 \\
\mathrm{~kg}\end{array}$ & 8 weeks & $\begin{array}{l}3 \mathrm{~g} / \mathrm{d} \\
\text { Capsu }\end{array}$ \\
\hline
\end{tabular}

\section{Progressive}

treadmill test

RPE « NR

Capsule of $1 \%$ and an

initial speed of 8

$\mathrm{km} \cdot \mathrm{h}^{-1}$ )

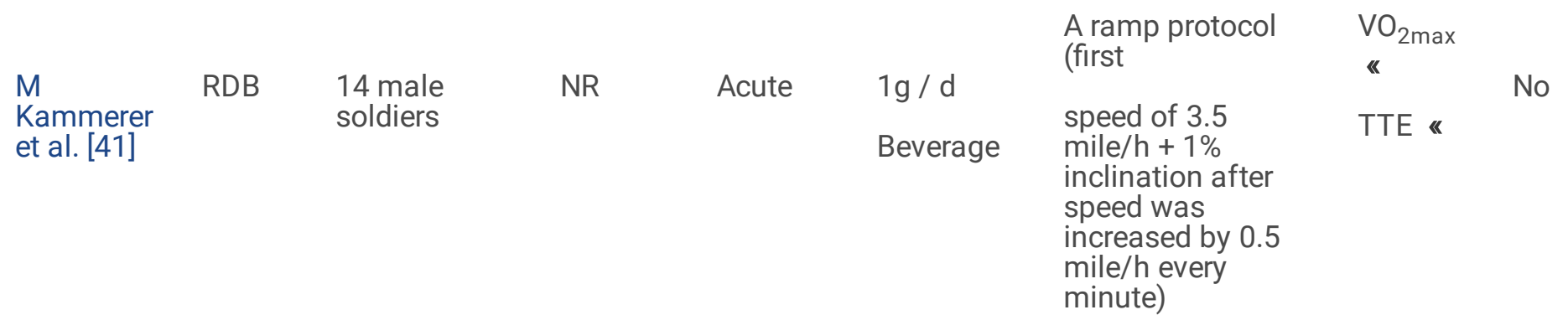

$\begin{array}{lllllll}\text { F Milioni } & \text { RCT } & \begin{array}{l}17 \text { male } \\ \text { trainees }\end{array} & 26 \mathrm{yr} / & \text { Acute } & 6 \mathrm{~g} / \mathrm{d} & \begin{array}{l}\text { Incremental } \\ \text { treadmill-running } \\ \text { et al. [14] }\end{array} \\ & & & \text { Capsule } & \text { test (submaximal } \\ & & & & \text { intensity }\left(7,5 \mathrm{~km} \cdot \mathrm{h}^{-}\right.\end{array}$

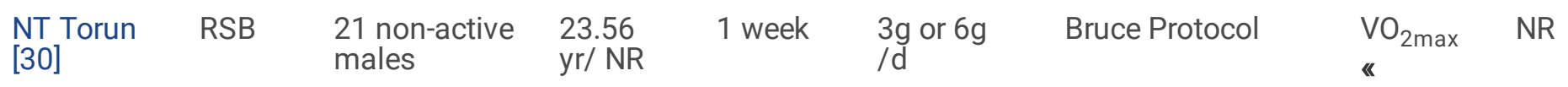

Capsules

\begin{tabular}{|c|c|c|c|c|c|c|c|}
\hline $\begin{array}{l}\text { JA } \\
\text { Rutherford } \\
\text { et al. [15] }\end{array}$ & $\mathrm{RCT}$ & $\begin{array}{l}11 \text { male } \\
\text { athletes }\end{array}$ & $\begin{array}{l}27.2 \mathrm{yr} / \\
74.3 \mathrm{~kg}\end{array}$ & Acute & $\begin{array}{l}1.66 \mathrm{~g} / \mathrm{d} \\
\text { Beverage }\end{array}$ & $\begin{array}{l}\text { Incremental cycle } \\
\text { test }(\sim 65 \%\end{array}$ & « \\
\hline
\end{tabular}


$\left.\mathrm{VO}_{2 \max }\right)$ to

exhaustion

\begin{tabular}{|c|c|c|c|c|c|c|}
\hline & $\mathrm{RDB}$ & $\begin{array}{l}9 \text { female } \\
\text { lacrosse } \\
\text { players }\end{array}$ & $\begin{array}{l}22 \mathrm{yr} / \\
65 \mathrm{~kg}\end{array}$ & 2 weeks & $\begin{array}{l}50 \\
\mathrm{mg} / \mathrm{kg} / \mathrm{d} \\
\text { Capsule }\end{array}$ & $\begin{array}{l}\text { Incremental ramp } \\
\text { exercise at } \\
\text { isokinetic high ( } 90 \\
\text { r/min) cadence }\end{array}$ \\
\hline
\end{tabular}

\begin{tabular}{|c|c|c|c|c|c|c|c|c|}
\hline $\begin{array}{l}\mathrm{M} \\
\text { Waldron } \\
\text { et al. [35] }\end{array}$ & $\mathrm{RDB}$ & $\begin{array}{l}12 \\
\text { recreationally } \\
\text { active males }\end{array}$ & $\begin{array}{l}23 \mathrm{yr} / \\
75.5 \mathrm{~kg}\end{array}$ & Acute & $\begin{array}{l}50 \\
\mathrm{mg} / \mathrm{kg} / \mathrm{d} \\
\text { Capsule }\end{array}$ & $\begin{array}{l}3 \text { minutes all-out } \\
\text { test on a cycle } \\
\text { ergometer }\end{array}$ & $\uparrow$ TTE & NR \\
\hline $\begin{array}{l}\text { R Ward et } \\
\text { al. [10] }\end{array}$ & RDB & $\begin{array}{l}11 \text { male } \\
\text { cyclists }\end{array}$ & $\begin{array}{l}34.6 \mathrm{yr} / \\
74,8 \mathrm{~kg}\end{array}$ & Acute & $\begin{array}{l}500 \mathrm{ml} \\
\text { water } \\
\text { containing } \\
1 \mathrm{~g} \text { of } \\
\text { taurine }\end{array}$ & $\begin{array}{l}4 \mathrm{~km} \text { time trial } \\
\text { performance on } \\
\text { ergometer }\end{array}$ & $\mathrm{VO}_{2 \max }$ & NR \\
\hline
\end{tabular}

$\begin{array}{llllllll}\mathrm{R} & \mathrm{RSB} & \begin{array}{l}7 \text { male team } \\ \text { sports } \\ \text { Warnock }\end{array} & \begin{array}{l}20 \mathrm{yr} / \\ 86.3 \mathrm{~kg}\end{array} & \text { Acute } & \begin{array}{l}50 \mathrm{mg} / \mathrm{kg} \\ \text { Capsule }\end{array} & \begin{array}{l}\text { Three Wingate } \\ \text { repeated sprint }\end{array} & \text { RPE « } \\ \text { et al. [29] } & & & & & \text { NR }\end{array}$

Abbreviations: RCT, randomized controlled trial; RDB: Randomised double-blind; RSB: Randomised single-blind; NR, Not reported; RM: repetition maximum; TT: Time trial; RPE: Rate of Perceived Exertion $\mathrm{VO}_{2 m a x}$ : Maximal oxygen uptake; TTE: Time to Exhaustion; g/d: gram/day; $\uparrow$ : significantly improve; $\downarrow$ : significantly decrease ; « : No significant difference. 


\begin{tabular}{|c|c|c|c|c|c|c|c|c|}
\hline $\begin{array}{l}\text { Author, } \\
\text { Year }\end{array}$ & $\begin{array}{l}\text { Study } \\
\text { design }\end{array}$ & $\begin{array}{l}\text { Sample } \\
\text { group and } \\
\text { total size }\end{array}$ & $\begin{array}{l}\text { Mean } \\
\text { age } \\
\text { (yr) } \\
\text { and } \\
\text { body } \\
\text { weight } \\
\text { (kg) }\end{array}$ & Duration & $\begin{array}{l}\text { Dosage } \\
\text { and form } \\
\text { of } \\
\text { Taurine }\end{array}$ & $\begin{array}{l}\text { Exercise } \\
\text { Protocols }\end{array}$ & Results & $\begin{array}{l}\text { Side } \\
\text { Effect }\end{array}$ \\
\hline $\begin{array}{l}\text { K Akalp } \\
\text { [39] }\end{array}$ & RDB & $\begin{array}{l}10 \text { active } \\
\text { males }\end{array}$ & $\begin{array}{l}21,4 \\
\mathrm{yr} / \\
75,2 \\
\mathrm{~kg}\end{array}$ & 1 week & $\begin{array}{l}0,1 \mathrm{~g} / \\
\mathrm{kg} \\
\text { Powder }\end{array}$ & $\begin{array}{l}\text { Chest press, } \\
\text { abdominal } \\
\text { crunch, and } \\
\text { leg } \\
\text { extension } \\
\text { exercises } \\
\text { (1RM 50\%) }\end{array}$ & $\begin{array}{l}\text { Blood Lactate } \\
\text { Level « } \\
\text { Vertical Jump « }\end{array}$ & NR \\
\hline $\begin{array}{l}\text { G Batitucci } \\
\text { et al. [36] }\end{array}$ & RDB & $\begin{array}{l}14 \text { male } \\
\text { swimmers }\end{array}$ & $\begin{array}{l}18-25 \\
\mathrm{yr} / \\
78.6 \\
\mathrm{~kg}\end{array}$ & 8 weeks & $\begin{array}{l}3 \mathrm{~g} / \mathrm{d} \\
\text { Capsule }\end{array}$ & $\begin{array}{l}400 \mathrm{~m} \text { front } \\
\text { crawl } \\
\text { swimming } \\
\text { performance }\end{array}$ & $\begin{array}{l}\text { Blood Lactate } \\
\text { Level } \uparrow\end{array}$ & NR \\
\hline $\begin{array}{l}\text { CC Dato } \\
\text { [31] }\end{array}$ & $\mathrm{RDB}$ & $\begin{array}{l}10 \text { male } \\
\text { swimmers }\end{array}$ & $\begin{array}{l}17-21 \\
\mathrm{yr} / 75 \\
\mathrm{~kg}\end{array}$ & Acute & $\begin{array}{l}6 \mathrm{~g} / \mathrm{d} \\
\text { Capsule }\end{array}$ & $\begin{array}{l}400 \mathrm{~m} \\
\text { swimming } \\
\text { performance }\end{array}$ & $\begin{array}{l}\text { Blood Lactate } \\
\text { Level « }\end{array}$ & NR \\
\hline $\begin{array}{l}\text { FG De } \\
\text { Carvalho } \\
\text { et al. [37] }\end{array}$ & $\mathrm{RDB}$ & $\begin{array}{l}9 \text { male } \\
\text { swimmers }\end{array}$ & $\begin{array}{l}19,8 \\
\mathrm{yr} / \\
76,3 \\
\mathrm{~kg}\end{array}$ & Acute & $\begin{array}{l}6 \mathrm{~g} / \mathrm{d} \\
\text { Capsule }\end{array}$ & $\begin{array}{l}400 \mathrm{~m} \text { front } \\
\text { crawl } \\
\text { swimming } \\
\text { performance }\end{array}$ & $\begin{array}{l}\text { Blood Lactate } \\
\text { Level « }\end{array}$ & NR \\
\hline $\begin{array}{l}\text { M } \\
\text { Kammerer } \\
\text { et al. [41] }\end{array}$ & $\mathrm{RDB}$ & $\begin{array}{l}14 \text { male } \\
\text { soldiers }\end{array}$ & NR & Acute & $\begin{array}{l}1 \mathrm{~g} / \mathrm{d} \\
\text { Beverage }\end{array}$ & $\begin{array}{l}\text { Three } \\
\text { vertical } \\
\text { jump trials }\end{array}$ & Vertical Jump « & No \\
\hline $\begin{array}{l}\text { A } \\
\text { Samandari } \\
\text { et al. [40] }\end{array}$ & $\mathrm{RDB}$ & $\begin{array}{l}10 \text { male } \\
\text { elite } \\
\text { taekwondo } \\
\text { athletes }\end{array}$ & $\begin{array}{l}20,6 \\
\mathrm{yr} / \\
67,1 \\
\mathrm{~kg}\end{array}$ & 10 days & $\begin{array}{l}15 \mathrm{mg} \\
/ \mathrm{kg} / \mathrm{d} \\
\text { Capsule }\end{array}$ & $\begin{array}{l}\text { Simulation } \\
\text { of } \\
\text { taekwondo } \\
\text { competition } \\
\text { day included } \\
\text { five } \\
\text { exhaustive } \\
\text { single } \\
\text { competition } \\
\text { exercises }\end{array}$ & $\begin{array}{l}\text { Countermovement } \\
\text { Jump « }\end{array}$ & No \\
\hline $\begin{array}{l}\text { E Kowsari } \\
\text { et al. [38] }\end{array}$ & $\mathrm{RDB}$ & $\begin{array}{l}20 \text { male } \\
\text { squash } \\
\text { players }\end{array}$ & $\begin{array}{l}25.1 \\
\mathrm{yr} / \\
97.8 \\
\mathrm{~kg}\end{array}$ & Acute & $\begin{array}{l}1 \mathrm{~g} / \mathrm{d} \\
\text { Capsule }\end{array}$ & $\begin{array}{l}\text { Bruce } \\
\text { Protocol }\end{array}$ & $\begin{array}{l}\text { Blood Lactate } \\
\text { Level } \downarrow\end{array}$ & NR \\
\hline
\end{tabular}




\section{Sub-Group Analysis Results of Individual Studies According to the Outputs}

Two distinct subgroup analyses of aerobic and anaerobic performance outputs were carried out in this study.

\section{The Effect Of Taurine Supplementation on Aerobic Performance Outputs}

11 studies were assessed aerobic performance outputs. 3 studies [14, 35, 41] reported the time to exhaustion (minutes), 2 studies $[10,16]$ reported $\mathrm{VO}_{2 \max }$ level $(\mathrm{ml} / \mathrm{kg} / \mathrm{min})$ and 6 studies $[15,16,29,32-34]$ measured rate of perceived exertion using the Borg scale (6 to 20 score). A total of 108 participants were reached with 10 studies.

Abbreviations: Green circle: low risk of bias; Red circle: high risk of bias; Blank space: unclear risk of bias. A: Random sequence generation; B: Allocation concealment bias; C: Blinding of participants and personnel; D: Blinding of outcome assessment; E: Incomplete outcome data; F: Selective reporting; G: Other bias; Cl: Confidence interval.

In a fixed effects model, taurine supplementation had no significant effect on $\mathrm{VO}_{2 \mathrm{max}}$ level and rate of perceived exertion (respectively, $\mathrm{MD}=-0.54 \mathrm{ml} / \mathrm{kg} / \mathrm{min} ; 95 \% \mathrm{Cl}$ [-6.84 to 5.75], $\mathrm{p}=0.87 ; \mathrm{MD}=-0.24 ; 95 \% \mathrm{Cl}[-0.74$ to 0.27$], \mathrm{p}=0.35$ ) when compared to a placebo group. In any case, taurine supplementation had a disposition moderate effect on time to exhaustion ( $\mathrm{MD}=0.43,95 \% \mathrm{Cl}[-0.31$ to 1.16$], \mathrm{p}=0.26)$ in moderate level. Heterogeneity degree $\left(\mathrm{l}^{2}\right)$ was calculated as $0 \%$ in all subgroups.

\section{The Effect Of Taurine Supplementation on Anaerobic Performance Outputs}

3 studies [39-41] analyzed vertical and countermovement jump as total height (cm). 3 studies [31, 36, 37] assessed blood lactate level as post-measure concentration (mmol/L). In total 6 studies (with 67 participants) were evaluated for anaerobic outputs.

Abbreviations: Green circle: low risk of bias; Red circle: high risk of bias; Blank space: unclear risk of bias. A: Random sequence generation; B: Allocation concealment bias; C: Blinding of participants and personnel; D: Blinding of outcome assessment; E: Incomplete outcome data; F: Selective reporting; G: Other bias; Cl: Confidence interval.

In a random-effects model, taurine supplementation had a significant effect on vertical ( $\mathrm{MD}=3.60 ; 95 \% \mathrm{Cl}$ [2.32 to 4.89], $\mathrm{p}$ $<0.00001)$ and countermovement ( $\mathrm{MD}=8.50 ; 95 \% \mathrm{Cl}$ [4.78 to 12.22], $\mathrm{p}<0.00001)$ jump performance when compared to a placebo group. Additionally, it was determined that taurine supplementation had no effect on blood lactate level (MD $=-0.56,95 \% \mathrm{Cl}[-1.82$ to 0.70$], \mathrm{p}=0.38$ ). While the level of heterogeneity for the vertical jump subgroup was $16 \%$ and $0 \%$ for the blood lactate level.

\section{Risk Of Bias}

Most of the studies had a low or unclear risk of bias. In 1 study [10] allocation concealment and blinding; in 2 studies [33, 34] incomplete outcome data, selective reporting, and other biases were unclear. The publication bias analysis is depicted in Figure 4.

The funnel plot of aerobic and anaerobic performance outputs revealed no significant publication bias because of symmetrical distribution except for a few studies.

\subsection{Side Effects}

In none of the trials, there were any negative consequences. 


\section{Discussion}

Although various roles of taurine in muscle have been reported, no specific mechanism has been reported for taurine that can increase muscle capacity or strength and reduce muscle damage. Therefore, this study focused on aerobic and anaerobic outputs to evaluate exercise performance. The current meta-analysis study provides up-to-date data for the literature on the effect of taurine intake on aerobic and anaerobic exercise performance. In total, 11 studies were selected for the evaluation of aerobic capacity and 6 studies for the evaluation of anaerobic capacity. Thus, the results of the metaanalysis indicate that taurine can be an effective ergogenic aid, especially on jumping performance, which is a marker of anaerobic output. The pooled effects of taurine on performance appear to be small, medium, and large. It should be noted that even small improvements in performance in some sports can translate into significant differences in competitive results $[42,43]$.

We found that taurine supplementation does not significantly affect neither aerobic (MD $=-0.03 ; 95 \% \mathrm{Cl}[-0.45$ to 0.39$]$; $\mathrm{p}=0.89$ ) nor anaerobic ( $\mathrm{MD}=2.08 ; 95 \% \mathrm{Cl}[-0.60$ to 4.76], $\mathrm{p}=0.13$ ) performance outputs. However, subgroup analysis showed a significant effect on jumping performance and it has been shown to have a moderate effect disposition on TTE.

To the best of our knowledge, the effects of taurine on aerobic and anaerobic performance have never been pooled in a meta-analysis before. It shows that taurine can cause practically significant improvements in jumping performance. For this reason, it is thought that taurine supplementation will be important in sports branches where jumping performance is at the forefront. In addition, athletes, trainers, and sports nutritionists should be informed about the ergogenic potential of taurine, and the outputs of this study can be used as a source for future scientific research.

\section{Aerobic Outputs}

$\mathrm{TTE}, \mathrm{VO}_{2 \mathrm{max}}$, and RPE parameters were used to evaluate aerobic exercise performance. In this study, it was determined that taurine had no effect on total aerobic performance, but showed a moderate effect on TTE. Taurine supplementation did not have a statistically significant effect on $\mathrm{VO}_{2 \max }$ and $\mathrm{RPE}$ according to this meta-analysis. Most studies

investigating the effect of taurine intake on aerobic performance have generally used the TTE parameter to assess aerobic capacity $[22,44,45]$. Results of individual studies evaluating aerobic performance reported a positive effect of taurine administration [22,44]. While the effect size of the improvement in taurine status was significant in these studies, it was seen that although there was no significant difference in TTE as a result of the meta-analysis in this study, it had a moderate effect size

The findings of the present meta-analysis are in line with previous research, as taurine intake has not been shown to affect $\mathrm{VO}_{2 \max }[8,16]$ and RPE $[16,44]$. In contrast, maximal oxygen uptake has been shown to increase up to exhaustion following taurine supplementation in individuals in an incremental cycle test $[22,46]$. However, the fact that oxygen uptake did not differ between conditions despite the significantly shorter completion time in the taurine intake case in the time trial could be interpreted as a positive effect of taurine uptake on central factors or muscle coordination independent of the metabolic effect. It has previously been suggested that the effect of taurine on exercise metabolism during simulated time trial performance would appear to act through interaction with the muscle. This is particularly important given that acute taurine intake not only increases muscle content but also plasma content [8]. Conversely, it is hypothesized that prior taurine intake may reduce taurine losses from muscle during aerobic exercise. However, a $1 \mathrm{~g}$ dose of taurine generally used in the studies included in the current meta-analysis would be sufficient to induce a concentration gradient by preventing muscle loss. Although it has been shown that the taurine content in muscle is decreased following aerobic exercise $[13,47]$, such studies have not been conducted yet, therefore further research is important to clarify the issue.

The effect of oral taurine on performance versus time has been inconsistent. For example, R Ward et al. [10] reported no effect of taurine on 4-km cycling time-trial performance, but TG Balshaw et al. [16] reported improvement in the $3 \mathrm{~km}$ time

Page 10/16 
trial. The energetics of exercise over long distances is largely reliant on capacity in the severe-intensity domain and based on the current findings, we would predict clear effects on closed-loop events of this distance. Indeed, ischemia preconditioning, beet juice, beta-alanine, and caffeine had equal or stronger effects on severe-intensity exercise TTE [4852]. As a result, although the explanation for the differences in research findings is not known clearly, the doses used and supplementation periods can still be associated with the training status of the individuals.

In an experimental investigation conducted by 11 male cyclists on a bicycle ergometer, it was revealed that $1 \mathrm{~g}$ of taurine supplement ingested before the $4 \mathrm{~km}$ time trial performance did not influence $\mathrm{VO}_{2 \max }$ [10]. In a double-blind randomized study examining the effects of acute administration of $1 \mathrm{~g}$ taurine on the $3 \mathrm{~km}$ time trial performance on a treadmill in middle-distance runners, it was stated that taurine supplementation did not influence $\mathrm{VO}_{2 \max }[16$ ]. M Zhang et al. [22], in their experimental study conducted with 11 healthy male individuals, exercised on a bicycle ergometer after the participants were given $6 \mathrm{~g}$ of taurine daily for 1 week. As a result, it has been reported that daily taurine supplementation of up to $6 \mathrm{~g}$ provides a significant improvement on $\mathrm{VO}_{2 \mathrm{max}}$. NT Torun [30], in his study with 21 healthy men, had the Bruce protocol applied, which is one of the maximally loaded treadmill methods, and after the protocol, the participants were included in a 1 week 3 and $6 \mathrm{~g}$ taurine loading process. As a result, it was observed that $\mathrm{VO}_{2 \max }$ increased significantly after $6 \mathrm{~g}$ taurine loading. It can be seen that the effects of taurine on the $\mathrm{VO}_{2 \max }$ parameter provide mixed outcomes. However, studies in the literature suggest that high dosages of $\geq 6 \mathrm{~g}$ may improve $\mathrm{VO}_{2 \mathrm{max}}$.

\section{Anaerobic Outputs}

Jumping performance (vertical and countermovement jumps) and blood lactate levels were used to assess anaerobic exercise performance. Taurine is known to increase $\mathrm{Ca}^{2+}$ transport to the sarcoplasmic reticulum, which aids skeletal muscle activation and muscle strength development $[47,53]$. Jumping is a complex action involving multiple joints that require high power and strength generation. Vertical jump distance has an important place among measurement methods in many sports branches $[54,55]$. Vertical jump performance is linked to maximal lower-body strength, according to several studies. Additionally, the rapid stretch provided by the countermovement jump, which is one of the most frequently used vertical jump tests, could lead to increased muscle activation and force production [56].

In this meta-analysis, it was observed that taurine intake significantly improved jumping performance. $\mathrm{K}$ Akalp [39], compared the measurements by performing the vertical jump test on 10 healthy men who took $0.1 \mathrm{~g} / \mathrm{kg}$ taurine 1 hour before and 1 hour, 24 hours, 48 hours, and 72 hours after strength exercise. As a result, the ability of taurine to reveal a statistically significant difference in vertical jump performance was determined. When the studies on the jumping performance of taurine intake were examined, no consensus has been reached. On the contrary, in an experimental study involving 10 male taekwondo athletes who were given an exercise protocol in which the taekwondo race day was simulated, it was stated that taurine supplementation of $15 \mathrm{mg} / \mathrm{kg}$ per day for 10 days was not effective on the countermovement jump performances of the athletes [40]. In a placebo-controlled double-blind study conducted with 14 healthy individuals, it was reported that $1 \mathrm{~g}$ of taurine consumed before 3 vertical jump trials did not have a statistically significant effect on vertical jump performance compared to placebo [41]. Although it was emphasized that taurine did not affect jumping performance due to the individual results of studies with different groups, taurine had a significant effect on jumping performance in this meta-analysis when compared to the placebo group.

The blood lactate-lowering effect of taurine is thought that most likely owing to a potential interaction between taurine and the calcium in mitochondrial buffering [57]. In this study, it was determined that taurine supplementation did not affect blood lactate levels. When the findings obtained from this meta-analysis are compared with the literature, various studies are reporting that taurine both does not $[16,31,37]$ and does affect $[36,38]$ blood lactate levels. It is thought that more studies are needed to examine whether taurine intake affects blood lactate levels. 


\section{Conclusion}

Taurine supplementation has a considerable significant effect on jumping performance $(p<0.0001)$, according to the results of experimental research conducted over the last 20 years. When compared to placebo, it had no ergogenic effect on aerobic outputs (RPE and $\mathrm{VO}_{2 \text { max }}$ ), although it may improve the TTE parameter. More controlled trials with a larger number of people and more diverse groups are needed to develop a consensus on taurine's ergogenic effects on sports performance and to extend these findings.

\section{Limitations}

The study's limitations include a lack of research, difficulties grouping due to the use of a wide variety of exercises, different doses and intervention periods, and a small sample size. The analysis of various athletes' competition levels is also another limitation of this study. Exercise protocols were asked to show concordance when aerobic and anaerobic performance were evaluated.

\section{Abbreviations}

RCT: randomized controlled trial; RDB: Randomised double-blind; RSB: Randomised single-blind; NR, Not reported; RM: repetition maximum; TT: Time trial; RPE: Rate of Perceived Exertion $\mathrm{VO}_{2 \mathrm{max}}$ : Maximal oxygen uptake; TTE: Time to Exhaustion; g/d: gram/day

\section{Declarations}

\section{Acknowledgments}

We sincerely thank all support from all authors

\section{Authors' contributions}

YB conceived the idea and conceptualized the review. YB, CDE, and ES conducted the study selection, data extraction, and methodological quality assessment. AT, KSZ drafted the initial manuscript. YB, CDE, AT, ES, and KSZ contributed to writing the manuscript. All authors read and approved the final manuscript.

\section{Funding}

The article has not received any funding or financial assistance from any institution or organization.

\section{Availability of data and materials}

The tables, figures, and supplemental materials supporting the conclusions of this article are included within the article.

\section{Declarations}

\section{Ethics approval and consent to participate}

Not applicable.

\section{Consent for publication}

Not applicable. 
There are no competing interests declared by the authors.

\section{Author details}

${ }^{1}$ Department of Coaching Training, Faculty of Sport Sciences, Erzurum Technical University, Erzurum, Turkey, ${ }^{2}$ Department of Nutrition and Dietetics, Faculty of Health Sciences, Near East University, Nicosia, Cyprus, ${ }^{3}$ Department of Physical Education and Sport, Faculty of Sport Sciences, Ibrahim Çeçen University, Ağrl, Turkey, ${ }^{4}$ Department of Physical Education and Sport, Faculty of Sport Sciences, Erzurum Technical University, Erzurum, Turkey, ${ }^{5}$ Department of Human Nutrition and Metabolomics, Pomeranian Medical University, Szczecin, Poland

\section{References}

1. Shihabi Z, Goodman H, Holmes R, O'connor M. The taurine content of avian erythrocytes and its role in osmoregulation. Comparative Biochemistry and Physiology Part A: Physiology. 1989; 92(4):545-549.

2. Schaffer S, Kim HW. Effects and mechanisms of taurine as a therapeutic agent. Biomolecules Therapeutics. 2018; 26(3):225.

3. De Luca A, Pierno S, Camerino DC. Taurine: the appeal of a safe amino acid for skeletal muscle disorders. Journal of Translational Medicine. 2015; 13(1):1-18.

4. $\quad$ Ripps H, Shen W. Taurine: a "very essential" amino acid. Molecular Vision. 2012; 18:2673.

5. Thirupathi A, Pinho RA, Baker JS, István B, Gu Y. Taurine reverses oxidative damages and restores the muscle function in overuse of exercised muscle. Frontiers in Physiology. 2020; 11.

6. Thirupathi A, Freitas S, Sorato HR, Pedroso GS, Effting PS, Damiani AP, Andrade VM, Nesi RT, Gupta RC, Muller AP. Modulatory effects of taurine on metabolic and oxidative stress parameters in a mice model of muscle overuse. Nutrition. 2018; 54:158-164.

7. Wen C, Li F, Zhang L, Duan Y, Guo Q, Wang W, He S, Li J, Yin Y. Taurine is involved in energy metabolism in muscles, adipose tissue, and the liver. Molecular Nutrition \& Food Research. 2019; 63(2):1800536.

8. Galloway SD, Talanian JL, Shoveller AK, Heigenhauser GJ, Spriet LL. Seven days of oral taurine supplementation does not increase muscle taurine content or alter substrate metabolism during prolonged exercise in humans. Journal of Applied Physiology. 2008; 105(2):643-651.

9. Ghandforoush-Sattari M, Mashayekhi S, Krishna CV, Thompson JP, Routledge PA. Pharmacokinetics of oral taurine in healthy volunteers. Amino Acids. 2010; 2010.

10. Ward R, Bridge CA, McNaughton LR, Sparks SA. The effect of acute taurine ingestion on 4-km time trial performance in trained cyclists. Amino Acids. 2016; 48(11):2581-2587.

11. Shao A, Hathcock JN. Risk assessment for the amino acids taurine, L-glutamine and L-arginine. Regulatory Toxicology and Pharmacology. 2008; 50(3):376-399.

12. Harris R, Wise J, Price K, Kim H, Kim C, Sale C. Determinants of muscle carnosine content. Amino Acids. 2012; 43(1):5-12.

13. Graham TE, Turcotte LP, Kiens B, Richter EA. Training and muscle ammonia and amino acid metabolism in humans during prolonged exercise. Journal of Applied Physiology. 1995; 78(2):725-735.

Page $13 / 16$ 
14. Milioni F, Malta EdS, Rocha LGSdA, Mesquita CAA, de Freitas EC, Zagatto AM. Acute administration of high doses of taurine does not substantially improve high-intensity running performance and the effect on maximal accumulated oxygen deficit is unclear. Applied Physiology, Nutrition, and Metabolism. 2016; 41(5):498-503.

15. Rutherford JA, Spriet LL, Stellingwerff T. The effect of acute taurine ingestion on endurance performance and metabolism in well-trained cyclists. International journal of sport nutrition and exercise metabolism. 2010; 20(4):322-329.

16. Balshaw TG, Bampouras TM, Barry TJ, Sparks SA. The effect of acute taurine ingestion on 3-km running performance in trained middle-distance runners. Amino Acids. 2013; 44(2):555-561.

17. Imagawa T, Hirano I, Utsuki K, Horie M, Naka A, Matsumoto K, Imagawa S. Caffeine and taurine enhance endurance performance. International Journal of Sports Medicine. 2009; 30(07):485-488.

18. Kerksick CM, Wilborn CD, Roberts MD, Smith-Ryan A, Kleiner SM, Jäger R, Collins R, Cooke M, Davis JN, Galvan E. ISSN exercise \& sports nutrition review update: research \& recommendations. Journal of The International Society of Sports Nutrition. 2018; 15(1):1-57.

19. Waldron $\mathrm{M}$, Patterson SD, Tallent J, Jeffries $\mathrm{O}$. The effects of an oral taurine dose and supplementation period on endurance exercise performance in humans: a meta-analysis. Sports Medicine. 2018; 48(5):1247-1253.

20. Da Silva LA, Tromm CB, Bom KF, Mariano I, Pozzi B, da Rosa GL, Tuon T, da Luz G, Vuolo F, Petronilho F. Effects of taurine supplementation following eccentric exercise in young adults. Applied Physiology, Nutrition, and Metabolism. 2014; 39(1):101-104.

21. Ra SG, Akazawa N, Choi Y, Matsubara T, Oikawa S, Kumagai H, Tanahashi K, Ohmori H, Maeda S. Taurine supplementation reduces eccentric exercise-induced delayed onset muscle soreness in young men. In: Taurine edn.: Springer; 2015: 765-772.

22. Zhang M, Izumi I, Kagamimori S, Sokejima S, Yamagami T, Liu Z, Qi B. Role of taurine supplementation to prevent exercise-induced oxidative stress in healthy young men. Amino Acids. 2004; 26(2):203-207.

23. Zembron-Lacny A, Szyszka K, Szygula Z. Effect of cysteine derivatives administration in healthy men exposed to intense resistance exercise by evaluation of pro-antioxidant ratio. The Journal of Physiological Sciences. 2007:343-348.

24. Chen Q, Li Z, Pinho RA, Gupta RC, Ugbolue UC, Thirupathi A, Gu Y. The Dose Response of Taurine on Aerobic and Strength Exercises: A Systematic Review. Frontiers in Physiology. 2021:1326.

25. Higgins JP, Altman DG, Gøtzsche PC, Jüni P, Moher D, Oxman AD, Savović J, Schulz KF, Weeks L, Sterne JA. The Cochrane Collaboration's tool for assessing risk of bias in randomised trials. BMJ. 2011; 343.

26. Morton RW, Murphy KT, McKellar SR, Schoenfeld BJ, Henselmans M, Helms E, Aragon AA, Devries MC, Banfield L, Krieger JW. A systematic review, meta-analysis and meta-regression of the effect of protein supplementation on resistance training-induced gains in muscle mass and strength in healthy adults. British Journal of Sports Medicine. 2018; 52(6):376384.

27. Jakubczyk K, Drużga A, Katarzyna J, Skonieczna-Żydecka K. Antioxidant Potential of Curcumin-A Meta-Analysis of Randomized Clinical Trials. Antioxidants. 2020; 9(11):1092.

28. Cohen J. Statistical power analysis. Current directions in psychological science. 1992; 1(3):98-101. 
29. Warnock R, Jeffries O, Patterson S, Waldron M. The effects of caffeine, taurine, or caffeine-taurine coingestion on repeat-sprint cycling performance and physiological responses. International Journal of Sports Physiology and Performance. 2017; 12(10):1341-1347.

30. Torun NT. Taurinin yorgunluğu geciktirme zamanı üzerine etkisinin incelenmesi. 2013.

31. Dato CC. Efeito da ingestão aguda de taurina sobre o desempenho físico e metabolismo lipídico de nadadores de elite de Ribeirão Preto. In.; 2014.

32. Waldron $M$, Knight $F$, Tallent J, Patterson $S$, Jeffries 0 . The effects of taurine on repeat sprint cycling after low or high cadence exhaustive exercise in females. Amino Acids. 2018; 50(6):663-669.

33. De Carvalho FG, Galan BS, Santos PC, Pritchett K, Pfrimer K, Ferriolli E, Papoti M, Marchini JS, De Freitas EC. Taurine: a potential ergogenic aid for preventing muscle damage and protein catabolism and decreasing oxidative stress produced by endurance exercise. Frontiers in Physiology. 2017; 8:710.

34. Galan BS, Carvalho FG, Santos PC, Gobbi RB, Kalva-Filho CA, Papoti M, Da Silva AS, Freitas EC. Effects of taurine on markers of muscle damage, inflammatory response and physical performance in triathletes. The Journal of sports medicine and physical fitness. 2017; 58(9):1318-1324.

35. Waldron M, Patterson SD, Jeffries O. Oral taurine improves critical power and severe-intensity exercise tolerance. Amino Acids. 2019; 51(10):1433-1441.

36. Batitucci G, Terrazas SIBM, Nóbrega MP, Carvalho FGd, Papoti M, Marchini JS, Silva ASRd, Freitas ECd. Effects of taurine supplementation in elite swimmers performance. Motriz: Revista de Educação Física. 2018; 24.

37. De Carvalho FG, Barbieri RA, Carvalho MB, Dato CC, Campos EZ, Gobbi RB, Papoti M, Silva AS, De Freitas EC. Taurine supplementation can increase lipolysis and affect the contribution of energy systems during front crawl maximal effort. Amino Acids. 2018; 50(1):189-198.

38. Kowsari E, Moosavi ZA, Rahimi A, Faramarzi M, Haghighi MM. The effect of short-term taurine amino acid supplement on neuromuscular fatigue, serum lactate level and choice reaction time after maximal athletic performance. Journal of Research in Medical and Dental Science. 2018; 6(1):358-364.

39. Akalp K. Taurinin akut egzersiz performansına ve toparlanmaya etkisi. Bursa Uludağ Üniversitesi; 2021.

40. Samandari A, Sanjideh F, Faramarzi M, Banitalebi E, Ghahfarrokhi MM. The Effects of Taurine Supplementation on Inflammatory Cytokines and Physical Performance to Simulated Taekwondo-Specific Protocol in Elite Male Athletes: A Double-Blinded, Placebo-Controlled, Crossover Study. 2021.

41. Kammerer M, Jaramillo JA, García A, Calderín JC, Valbuena LH. Effects of energy drink major bioactive compounds on the performance of young adults in fitness and cognitive tests: a randomized controlled trial. Journal of The International Society of Sports Nutrition. 2014; 11(1):1-7.

42. Le Meur Y, Hausswirth C, Mujika I. Tapering for competition: A review. Science \& Sports. 2012; 27(2):77-87.

43. Pyne DB, Mujika I, Reilly T. Peaking for optimal performance: Research limitations and future directions. Journal of sports sciences. 2009; 27(3):195-202.

44. Lee H, Paik I, Park T. Effects of dietary supplementation of taurine, carnitine or glutamine on endurance exercise performance and fatigue parameters in athletes. Korean Journal of Nutrition. 2003; 36(7):711-719. 
45. Alford $\mathrm{C}, \mathrm{Cox} \mathrm{H}$, Wescott R. The effects of red bull energy drink on human performance and mood. Amino Acids. $2001 ; 21(2): 139-150$.

46. Carvalho MBD, Brandao CFC, Fassini PG, Bianco TM, Batitucci G, Galan BSM, Carvalho FGD, Vieira TS, Ferriolli E, Marchini JS. Taurine supplementation increases post-exercise lipid oxidation at moderate intensity in fasted healthy males. Nutrients. 2020; 12(5):1540.

47. Cuisinier C, Ward RJ, Francaux M, Sturbois X, De Witte PJAA. Changes in plasma and urinary taurine and amino acids in runners immediately and $24 \mathrm{~h}$ after a marathon. Amino Acids. 2001; 20(1):13-23.

48. Lacour J, Padilla-Magunacelaya S, Barthelemy J, Dormois D. The energetics of middle-distance running. European journal of applied physiology and occupational physiology. 1990; 60(1):38-43.

49. Griffin PJ, Ferguson RA, Gissane C, Bailey SJ, Patterson SD. Ischemic preconditioning enhances critical power during a 3 minute all-out cycling test. Journal of Sports Sciences. 2018; 36(9):1038-1043.

50. Kelly J, Vanhatalo A, Wilkerson DP, Wylie LJ, Jones AM. Effects of nitrate on the power-duration relationship for severe-intensity exercise. Med Sci Sports Exerc. 2013; 45(9):1798-1806.

51. Black MI, Jones AM, Morgan PT, Bailey SJ, Fulford J, Vanhatalo A. The effects of $\beta$-alanine supplementation on muscle $\mathrm{pH}$ and the power-duration relationship during high-intensity exercise. Frontiers in physiology. 2018; 9:111.

52. Silveira R, Andrade-Souza VA, Arcoverde L, Tomazini F, Sansonio A, Bishop DJ, Bertuzzi R, Lima-Silva AE. Caffeine increases work done above critical power, but not anaerobic work. Medicine and science in sports and exercise. 2018; 50(1):131-140.

53. Mueller E, Rado L, Weise M, Cass T. Effects of red bull on Wingate testing of college aged students. Official Research Journal of the Department of Kinesiology University of Wisconsin. 2007.

54. Aragón LF. Evaluation of four vertical jump tests: Methodology, reliability, validity, and accuracy. Measurement in physical education and exercise science. 2000; 4(4):215-228.

55. Rahimi R, Behpur N. The effects of plyometric, weight and plyometric-weight training on anaerobic power and muscular strength. Facta universitatis-series: Physical Education and Sport. 2005; 3(1):81-91.

56. Sole CJ. Analysis of countermovement vertical jump force-time curve phase characteristics in athletes. East Tennessee State University; 2015.

57. El Idrissi A. Taurine increases mitochondrial buffering of calcium: role in neuroprotection. Amino Acids. 2008; 34(2):321-328. 